\title{
Research on land use characteristics in the metropolitan TOD region
}

\author{
Wenxiao $\operatorname{Yan}^{1,2,3^{*}}$ \\ ${ }^{1}$ Shanghai Institute of Geological Survey, Shanghai, China \\ ${ }^{2}$ Shanghai Institute of Land Resource Survey, Shanghai, China \\ ${ }^{3}$ Shanghai Land Policy Empirical Research Base of China Land Survey and Planning Institute, Shanghai, China
}

\begin{abstract}
Taking Guangzhou as an example, the land use structure characteristics of the TOD area centered on the rail transit station are studied. The TOD area land use specificity index E is constructed, through the preliminary calculation of Guangzhou city index, using the natural break point grading method, the index according to the appropriateness of TOD area construction land is divided into TOD area significantly suitable for construction land, generally suitable construction land, non-specific construction land, generally not suitable for construction land, significantly inappropriate construction land five categories. By analyzing the various types of construction land in Guangzhou and the appropriateness of the TOD area of the rail transit site, the development strategy is provided for the development of the city guided by the TOD area of rail transit.
\end{abstract}

\section{Preface}

There is a complex interaction between urban transportation and urban land development. The development mode (TOD mode) which uses public transportation to guide urban development, has become the main development mode of metropolis. The concept of TOD model has been put forward for nearly thirty years and is put forward in the context of the development of new urbanism in the United States. Taking Guangzhou as an example, this study analyses the land use characteristics of TOD model under the background of the construction of China's public transportation with rail transit as the leading and largedevelopment, and provides the development strategy for the development of the city guided by the rail transit TOD under the new situation of China.

\section{Relevant concepts and theories}

TOD model is a way to realize the concept of coordinated development of public transportation and land use. The representative of new urbanism in 1993 is a public transport-oriented urban land development model. And it is one of the important means to alleviate urban traffic problems. This development model is characterized by a mix of land use which usually contains a certain number of commercial, office, public service, residential, etc. A standard TOD consists mainly of core business districts, office/employment areas, public/open spaces, residential areas, sub-regions. TOD areas can be subdivided into urban center, urban neighbourhood, regional city center, suburban neighborhood, university center and other development models. The TOD area is defined ten-minutes' walk from the public transport station on the spatial scale. In this study, the area within 800 meters of the rail transit station is used as the TOD area of the rail transit.

There is a very complicated relationship between urban transportation and urban land development and utilization. From the point of view of land use, the main function of rail transit station is the distribution of people, suitable for the layout of large traffic of public distribution, public service functional land. At the same time, the rail transit station improves the land value, the general core area development intensity is high, suitable for the layout of commercial and commercial functional land, peripheral areas or suburban TOD areas to residential functions.

\section{Subjects and methods of study}

Rail transit is the most typical public transport in metropolitan areas which has fast speed and large capacity. While the subway line is fixed, it has the strongest driving role of land development. Therefore, this study uses rail transit as the representative of public transportation, the land use in the TOD area around the rail transit station as the research object, and the city of Guangzhou as an example, studies the characteristics of land use around the rail transit station.

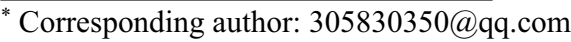




\section{Land use characteristics of Guangzhou rail transit TOD area}

By analysing the type of construction land in the TOD area of Guangzhou rail station and comparing the type of construction land in the non-TOD area, the land use characteristics of the TOD area are studied. (Data from the Master Plan of Guangzhou (2017-2035) and related topics).

\subsection{The land use feature model of the rail intersecting site}

First of all, to define the TOD area of Guangzhou city land area through GIS buffer and Tyson polygon analysis combined with the rail transit site of 800 meters radiation radius coverage area of the current land. Statistical analysis of the proportion of various types of construction land area in this range calculated Guangzhou TOD area construction land specificity index E.

$$
E_{x}=\left(S_{x}^{\prime} S_{t}-S_{x} / S_{)} / S_{x} / S\right.
$$

Among them, Ex is the specific index of a certain $x$ construction land, S'x is the area of $\mathrm{x}$ construction land in the TOD area, St is the total area of construction land in the TOD area, Sx is the area of the city $\mathrm{x}$ type of construction land, $\mathrm{S}$ is the total area of the city's construction land.

\subsection{TOD area construction land specific evaluation criteria}

According to the E-value of the specificity index of various types of construction land in Guangzhou, the specificity index $\mathrm{E}$ is divided into 5 categories by using the natural break point grading method (Jenks). To identify the locations where the specificity of various types of construction land is more varied which means this kind of construction land adjust slightly.

When the specificity index $\mathrm{E}$ is greater than 0 indicates that the proportion of such construction land in TOD area is greater than that of non-TOD area. That means it is the suitable layout of such construction land in TOD area. The type of construction land with E value greater than 1.00 is significantly suitable construction land in TOD area, the proportion of such construction land in TOD area is significantly larger than that of nonTOD area, and the development of TOD area has a significant mutual promotion role, the development of TOD area should be actively encouraged to develop this type of construction land. The type of construction land between $0.51-1.00$ is generally suitable construction land in TOD area, and the proportion of construction land in TOD area is to some extent larger than that of non-TOD area, which has mutually promoted relationship with the development of TOD region, and is the type of construction land suitable for development in TOD area. On the other verse, when the specificity index E is less than 0 indicates that the proportion of such construction land in TOD area is smaller than that in non-TOD area.
Which means the construction land of this type is not suitable for layout in TOD area.

Table 1. Classification criteria for the specificity index of the TOD region of rail transit.

\begin{tabular}{|c|c|}
\hline $\begin{array}{c}\text { The value range } \\
\text { of the specificity } \\
\text { index of TOD } \\
\text { area construction } \\
\text { land E }\end{array}$ & $\begin{array}{c}\text { The specificity of this kind } \\
\text { of construction land in TOD } \\
\text { area }\end{array}$ \\
\hline$>1.00$ & $\begin{array}{c}\text { suitable for construction land } \\
\text { in the TOD area }\end{array}$ \\
\hline $0.51-1.00$ & $\begin{array}{c}\text { TOD area is generally } \\
\text { suitable for construction land }\end{array}$ \\
\hline$-0.40--0.50$ & $\begin{array}{c}\text { Non-specific construction } \\
\text { land in the TOD area }\end{array}$ \\
\hline$-0.50---0.41$ & $\begin{array}{c}\text { TOD area is generally not } \\
\text { suitable for construction land }\end{array}$ \\
\hline$<-0.50$ & $\begin{array}{c}\text { TOD area is significantly } \\
\text { unsuitable for construction } \\
\text { land }\end{array}$ \\
\hline
\end{tabular}

\subsection{Analysis of the specificity index of construction land in TOD area of Guangzhou rail intersecting site}

According to the Standard of Urban Land Classification and Planning and Construction Land (GB50137-2011) (hereinafter referred to as the Standard), the construction land in TOD area of Guangzhou is divided into three major areas: urban construction land, rural construction land and other construction land. Urban and rural construction land includes urban construction land (H11) town construction land (H12) and township construction land (H13). According to the classification criteria of urban construction land subdivided into the middle category which contains seven types including residential land, public management and public service facilities land, commercial services facilities land, industrial logistics storage land, road traffic facilities land, utility land, green space and square land.

Table 2. the proportion of construction land.

\begin{tabular}{|c|c|c|c|c|}
\hline \multicolumn{3}{|c|}{ Classification of construction land } & $\begin{array}{c}\text { The } \\
\text { proportion } \\
\text { of all types } \\
\text { of } \\
\text { constructio } \\
\text { n land }\end{array}$ & $\begin{array}{l}\text { The } \\
\text { proportion } \\
\text { of all types } \\
\text { of } \\
\text { constructio } \\
\mathrm{n} \text { land in } \\
\text { TOD } \\
\text { region }\end{array}$ \\
\hline \multirow{3}{*}{$\begin{array}{c}\text { Constructio } \\
\mathrm{n} \text { land for } \\
\text { urban and } \\
\text { rural } \\
\text { residents }\end{array}$} & \multicolumn{2}{|c|}{$\begin{array}{l}\text { Land for urban } \\
\text { construction }\end{array}$} & $59.29 \%$ & $82.29 \%$ \\
\hline & \multirow[b]{2}{*}{$\begin{array}{c}\text { whic } \\
\mathrm{h}\end{array}$} & $\begin{array}{l}\text { Residential } \\
\text { land }\end{array}$ & $13.85 \%$ & $26.88 \%$ \\
\hline & & $\begin{array}{c}\text { Land for } \\
\text { public } \\
\text { administratio } \\
\text { n and public } \\
\text { service } \\
\text { facilities }\end{array}$ & $7.32 \%$ & $14.27 \%$ \\
\hline
\end{tabular}




\begin{tabular}{|c|c|c|c|c|}
\hline & $\begin{array}{c}\text { Land for } \\
\text { commercial } \\
\text { service } \\
\text { facilities }\end{array}$ & $4.50 \%$ & $11.34 \%$ \\
\cline { 2 - 4 } & $\begin{array}{c}\text { Industrial, } \\
\text { logistics and } \\
\text { storage land }\end{array}$ & $18.07 \%$ & $8.66 \%$ \\
\cline { 2 - 4 } & $\begin{array}{c}\text { Land for } \\
\text { roads and } \\
\text { transport } \\
\text { facilities }\end{array}$ & $10.87 \%$ & $14.90 \%$ \\
\cline { 2 - 4 } & $\begin{array}{c}\text { Public utility } \\
\text { land }\end{array}$ & $1.80 \%$ & $1.02 \%$ \\
\cline { 2 - 4 } & $\begin{array}{c}\text { Green space } \\
\text { and square } \\
\text { land }\end{array}$ & $2.87 \%$ & $5.22 \%$ \\
\cline { 2 - 4 } & Land for village \\
construction & $26.97 \%$ & $10.96 \%$ \\
\hline \multicolumn{2}{|c|}{ Other construction sites } & $13.74 \%$ & $6.75 \%$ \\
\hline
\end{tabular}

Driving the development of surrounding land through rail construction has become one of the important models of land development in big cities. The TOD area of the rail transit site developed recent years is still under construction. Therefore, the TOD area defined within the 800 -meter coverage of Guangzhou rail transit station contains $27 \%$ of the village construction land and $14 \%$ of the regional transportation, special land and other construction land. The construction land in the unfinished TOD area is not used as the research object of the land use characteristics in the TOD area. Therefore, only the construction land of the seven types mentioned in the previous paragraph, such as residential land, public management and public service facilities land is evaluated.

Table 3. TOD regional specificity index and evaluation of rail transit in Guangzhou.

\begin{tabular}{|c|c|c|}
\hline $\begin{array}{c}\text { Classification of } \\
\text { construction land }\end{array}$ & $\mathrm{E}$ & $\begin{array}{c}\text { Evaluation of the } \\
\text { specificity }\end{array}$ \\
\hline Residential land & 0.94 & $\begin{array}{c}\text { generally suitable for } \\
\text { construction land }\end{array}$ \\
\hline $\begin{array}{c}\text { Land for public } \\
\text { administration and } \\
\text { public service facilities }\end{array}$ & 0.95 & $\begin{array}{c}\text { TOD area is generally } \\
\text { suitable for construction } \\
\text { land }\end{array}$ \\
\hline $\begin{array}{c}\text { Land for commercial } \\
\text { service facilities }\end{array}$ & 1.52 & $\begin{array}{c}\text { significantly suitable for } \\
\text { construction land }\end{array}$ \\
\hline $\begin{array}{c}\text { Industrial, logistics and } \\
\text { storage land }\end{array}$ & -0.52 & $\begin{array}{c}\text { significantly unsuitable } \\
\text { for construction land }\end{array}$ \\
\hline $\begin{array}{c}\text { Land for roads and } \\
\text { transport facilities }\end{array}$ & 0.37 & $\begin{array}{c}\text { non-specific construction } \\
\text { land }\end{array}$ \\
\hline Public utility land & -0.43 & $\begin{array}{c}\text { generally not suitable for } \\
\text { construction land }\end{array}$ \\
\hline $\begin{array}{c}\text { Green space and square } \\
\text { land }\end{array}$ & 0.82 & $\begin{array}{c}\text { generally suitable for } \\
\text { construction land }\end{array}$ \\
\hline
\end{tabular}

According to the table above, we think that there is no specificity except when the land index value of road traffic facilities is between -0.40 and 0.50 . When the TOD area construction land index $\mathrm{E}$ is greater than 0 , from high to low, there are four types including commercial service facilities land, residential land, public management and public service facilities land, green space and square land. The absolute value of the index is mainly between $0.82-1.52$. When the TOD area construction land index $\mathrm{E}$ is less than 0 and the absolute value of the index from the high to low, there are two kinds including industrial storage logistics land and public facilities land. Its absolute value of the indicator is between 0.4-0.52. The absolute value of $E$ value significantly greater than 0 is significantly greater than the absolute value of $E$ value less than 0 , indicating that the suitability of construction land in TOD area is more significant, and the four types of construction land including commercial service facilities, residential land, public management and public service facilities, green space and square land are significantly suitable for TOD area. The difference between the lands with $\mathrm{E}$ value higher than 0 is significantly greater than the difference between the lands with $\mathrm{E}$ value lower than 0. Indicating that the suitability of different kinds of construction land is different.

In the TOD area of Guangzhou, the construction land index $\mathrm{E}$ is greater than 0 . that is, significantly suitable for construction land commercial service facilities land is commercial service facilities land. Its TOD area construction land specificity index $\mathrm{E}$ reached 1.52, indicating that the proportion of commercial service facilities in TOD area is more than 1.5 times higher than other areas, significantly higher than other types of construction land. TOD area is generally suitable for construction land has public management and public service construction land, residential land, green space and square land three categories, the proportion of these three types of land in TOD area is significantly higher than other areas. Roads and traffic land are not obviously specific. There are two types of construction land index E less than 0 , the construction land that is obviously not suitable is industrial, storage and logistics land, and the construction land that is generally not suitable is utility land.

\subsection{The development characteristics of land use in TOD area of Guangzhou rail intersecting site}

The main functional areas in the TOD definition are "core business district, office/employment area, public/open space, residential area, secondary area". From the evaluation results, Guangzhou rail transit site around the TOD area is the most specific, the most suitable construction land is commercial service facilities land, with the TOD definition of the "core business district" function, but also can carry office / employment functions. Guangzhou rail transit site TOD area is generally suitable for residential land, green space square land and TOD definition of residential areas, public/ open space coincide, but slightly different from the TOD definition is the Guangzhou rail transit site TOD area carrying public /open space function of green space and square land specificity index is significantly smaller than the residential land carrying residential function, and from the definition of TOD, the function of public/open space should take precedence over the residential function. The public service function carried by the land of public management and public service facilities in the construction land of Guangzhou rail transit TOD, which is second only to the land of commercial service facilities, is not emphasized in the definition of TOD. 
From the evaluation results, Guangzhou rail transit site as the center of the TOD area of the land function structure and TOD definition basically coincide, commercial, office function is still the core function of TOD area, public open space, housing is also an important part of TOD function. However, there has been a certain development and evolution, administrative office, cultural education, health care and other public management and public service functions in Guangzhou Rail Transit TOD area has become second only to commercial, office functions of the important functions, public open space compared to the traditional TOD definition has decreased, and the importance of residential functions has increased. This is related to the low volume ratio of public open space and the fact that the rising low prices in the TOD region do not match.

\section{Conclusion and reflection}

\subsection{Strengthen the coordination of rail transit planning and land use planning}

Rail transit planning has an important guiding role in urban space development, and has obvious interaction and interaction with land use. Rail transit station brings the flow of people and promotes the value of surrounding land, so that the TOD area around the site forms a certain land use model. Land use planning around the site in line with this model can better play the role of rail transit sites, to maximize the land value of the TOD area around the site.

\subsection{Commercial service facilities to promote the development of TOD region}

From the evaluation and analysis results, the commercial service facilities land is the most typical land in THED area, and the commercial business function carried on it is the core of TOD regional development. Rail transit station can drive the development of commercial commerce, the development of commercial business can further gather people to drive the development of surrounding living, public services and other functions, thereby driving the development of land throughout the region. Land development in the new area can take commercial service facilities as the guide, driving the development of the whole TOD area, thus driving the land development of the whole area.

\subsection{The establishment of appropriate land reserve supply mechanism}

China's urbanization process is still developing rapidly, TOD-led urban land development is also large-scale. According to the characteristics of land use in TOD area, the appropriate land reserve and land supply policy mechanism is formulated to guide the rationality of land use and land development, so as to guide the implementation of planning, realize the optimal allocation and efficient use of land resources, and promote the transformation of land development from extensive to conservation intensive utilization.

\section{References}

1. California Development of Transportation. The Statewide Transit Direct Development: Factors for Success in California Final eport . California: California Department of Transportation, 2002.

2. Robert Cervero. The Property Value Case for Transit. Development Around Transit. Washington, DC: The Urban Land Institute, 2004: 31-52.

3. John L Renne. Transit-Development: Measuring Benefits. Analytic Trends, and Evaluating Policy. Rutgers State University PHD Dissertation.2005:615.

4. Hongbo Du, Corinne Mulley. The Short-term Land Value Impacts of Urban Rail Transit: Quantitative Evidence From Sunderland . Land Use Policy, 2007: 223-233.

5. Liu Y, Peng J, et al. Psola: a heuristic Land-Use allocation model using Patch-Level operations and Knpwledge-Informed rules. PLOS One., 2016, 11 (6): e0157728.

6. Guangzhou City Master Plan (2017-2035).

7. "Urban Land Classification and Planning and Construction Land Standards" (GB50137-2011). 